\title{
Combination of a Coastal Vulnerability Index (CVI) and social economic approaches in prioritizing the development of Riau Coastlines, Indonesia
}

\author{
Ari Sandhyavitri ${ }^{1 *}$, Ferry Fatnanta $^{1}$, Rizki Ramadhan Husaini ${ }^{1}$, and Imam Suprayogi ${ }^{1}$ \\ ${ }^{1}$ Department of Civil Engineering, Universitas Riau, Pekanbaru, Indonesia
}

\begin{abstract}
The length of Riau coastlines, Indonesia were approximately $900 \mathrm{~km}$ long. Hence, there has been difficulty in prioritizing managing various locations of the coastline damages based on a systematic approach. The objectives of this paper are to apply the state of art in the identification of 16 major coastlines vulnerability index in Riau, and to prioritizing which coastlines should be managed in terms of 4 main aspects such as; technical aspect, economic, environmental, and strategic one. The methodology applied in this paper utilized the combination of the Coastal Vulnerability Index (CVI) and social economic approaches using a Likert's scale of 1 (low) to 5 (very high). This study has recommended a priority in managing the coastlines in Riau was as follow; Pambang Pesisir, Bengkalis and Tanah Merah, Meranti Islands. These coastlines were calculated as the very high level of vulnerability indexes of 75.3 and 74.9 respectively. This study also simulated the use of shoreline protection structure by Genesis software utilizing a revetment construction. The results showed that the construction of revetment structure in Pambang pesisir beach may reduce the shore erosion rate from $10 \mathrm{~m} / 14$ year to $0 \mathrm{~m}$ $/ 14$ year.
\end{abstract}

\section{Introduction}

Indonesia is the largest archipelagic country in the world consisting of 17,508 islands with a coastline of $81,000 \mathrm{~km}$, and this condition appointed Indonesia coastline as the second longest coastline in the world after Canada [1]. The coast is considered as the outside area close to the border zone of the Unitary State of the Republic of Indonesia. The development of economic, social and technology causes overexploitation of the existing natural resources on the coast so that the carrying capacity of the coastal areas tend to decline [2].

Bengkalis and Meranti are the regencies locating at the outermost islands in Riau Province where the islands are directly bordered to the Malacca Strait which are close to Malaysia and Singapore (Fig. 1). The southern part Bengkalis has experienced the high

* Corresponding author: ari.sandhyavitri@1ecturer.unri.ac.id 
degree of sedimentation process. In the last 26 years (1990-2016) there has been abrasion occurred in a northern part of Bengkalis Island with an average rate of $59 \mathrm{ha} / \mathrm{year}$, and a sedimentation rate of $16.5 \mathrm{ha} /$ year. This indicates that Bengkalis Island experienced a substantial reduction of the existing land area at the average rate of 42.5 ha/year. These critical beach areas were considered in need to be mitigated. According to Sandhyavitri [3] the northern part of Bengkalis Island, and Meranti Island, Riau Province, Indonesia has experienced the most severe abrasion occurrences compared to the other areas (Fig. 1).
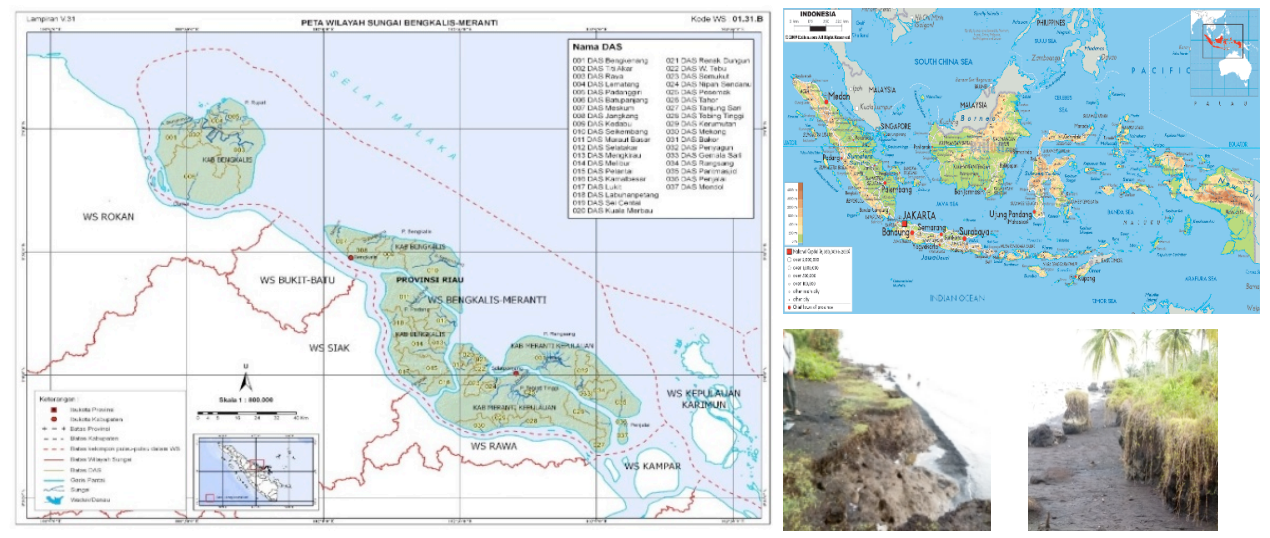

Fig. 1. Research location

The research location of this study is in Riau Province encompassing Bengkalis and Meranti Islands Regency. These areas may encompass; Rupat Island, Bengkalis Island, and Rangsang Island covering $900 \mathrm{~km}$ of coastlines. The study objectives are to identify the coastal vulnerability in the Riau Province, Indonesia by utilizing the combination of Coastal Vulnerability Index (CVI) and social, economic approaches, then mitigating the existing severe coastal faults by conducting simulation the shoreline changes using a GENESIS application software package. The CVI and social approach were assessed using four main variables, namely physical, socio-economy, environment, and strategic variables.

\subsection{Coastal physical vulnerability variables}

According to Kaiser [4], a coastal physical vulnerability variable is perceived as a condition of "susceptibility" state of a natural system as well as a social state of the coastal ecology (human, group or community) which were affected by the degradation of the coastal conditions. Doukakis [5] divides coastal physical vulnerability variables into four categories, namely: low-moderate-high-very high. The classes are based on the calculation of the coastal risk variables encompassing coastal slope, land subsidence, shoreline changes, geomorphology conditions, wave heights and level of the tides high.

This study considered ten coastal physical vulnerability variables such as 1) Coastal Line Changes (PP), 2) Visual Damage Observation (K), 3) Length of Damage (PK), 4) The Width of Damage (LK), 5) Green Belt Width (SH), 6) Lithology (L), 7) High Wave (H), 8). Tidal range (PS), 9) Land Use (PL), and 10) Beach Slope (tan $\alpha$ ). Based on the calculation of 10 coastal physical variables, the Coastal Vulnerability Index (CVI) was then calculated [5-10]. In this study the (CVI) was calculated as follows:

$$
\operatorname{IKP}(\mathrm{CVI})=(\sqrt{ }(\text { Multiplication of all variables }) /(\text { Number of Variables }))
$$

Boruff [6] compiled a coastal physical vulnerability classification is based on the index value of vulnerability levels (IKP) as in Table 1. 
Table 1. Coastal vulnerability levels.

\begin{tabular}{|c|c|c|c|c|}
\hline IKP (CVI) & $0-25$ & $25-50$ & $50-75$ & $>75$ \\
\hline Vulnerability & Low & Moderate & High & Very high \\
\hline
\end{tabular}

\subsection{Overview of the socio-economic, environmental and strategic aspects}

The economic aspects which are considered affect to the CVI involve six parameters, consists of the financial condition of the society living within the area, the risks concerning declining community income, decreasing in the number of business activities, unemployment risk, the threat to deteriorating the existing pond conditions, declining in plantation areas, and agriculture areas [11].

The social aspects are divided into five parameters, namely fisherman settlements, public and commercial facilities, protected tree from felling, damaged beaches affecting liquefaction, damaged beaches affect to remove school and building infrastructures.

The environmental aspects of CVI may include three parameters such as accessibility, natural conservation, and wastes.

The strategic aspects may encompass four parameters, namely 1) The National Spatial Strategic Planning (based on the Government Regulation of the Republic of Indonesia No. 13 of 2017 concerning the National Spatial Planning, RTRWN), 2) The National Tourism Strategic Plan (Regulation Government of the Republic of Indonesia Number 50 the year 2011 concerning Master Plan of the National Tourism Development Year 2010-2025), 3) Local Strategic Planning of the Riau Province, and 4) Port Strategic Development Zones.

\subsection{Likert scale}

According to Sugiyono [12], the Likert scale is used as a reference in the processing of data from the questionnaire. The quantitative method used in the weighting of the coast vulnerability index based on the Likert's Summated Rating (SLR) Scale. The Likert's scale is used to measure attitudes, opinions, and perceptions of a person or group concerning the technical, social and economic events [13]. Likert scale in this paper is grouped in the following scales (Table 2).

Table 2. Likert scales.

\begin{tabular}{|c|c|l|}
\hline Category & Scale & \multicolumn{1}{|c|}{ Score } \\
\hline Low (L) & 1 & $1.00-1.79$ \\
\hline Middle (M) & 2 & $1.80-2.59$ \\
\hline High (H) & 3 & $2.60-3.37$ \\
\hline Very High (VH) & 4 & $3.38-4.16$ \\
\hline Very Very High (VVH) & 5 & $4.17-5.00$ \\
\hline
\end{tabular}

1.4 Beach safety with the application of revetment structure 
In general, coastal structures are built on the locations where coastal erosion causes serious problems. The decision in constructing a coastal structure should be based on a systematic analysis of the coastline conditions and forecasts the shoreline deterioration rates.

A revetment is one of the coastal construction options which will be used in this study. A revetment is a land structure (onshore structure) which is in principle applied to reduce erosion rates. In general, the revetment structure is constructed using various materials such as stone, concrete, or asphalt. The revetment is installed parallel to the beach and attached to the shoreline cliffs. The revetment structure can be seen in Fig. 2.

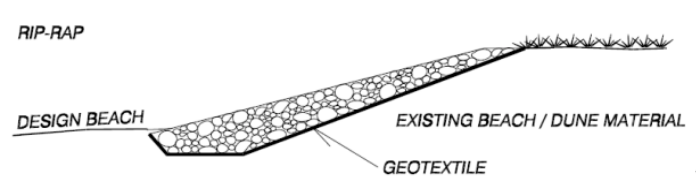

(a)

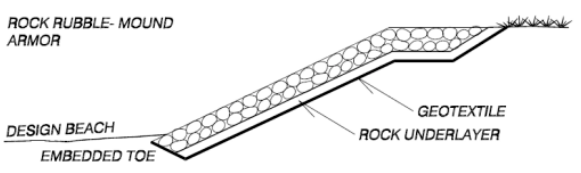

(b)

Fig. 2. Examples of revetment structures (a) rip-rats of composite cobbles, (b) broken stone structures.

\section{Methodology}

Primary data consist of the coastal physical condition and damage, including damaged infrastructures, and land use was obtained from the field investigation. Secondary data such as wind speed, fluctuation of tides, rainfall data, The geological map, and satellite images were collected from various sources.

\subsection{A weighting measure for obtaining the coastal physical variables}

The variables used in assessing the Coastal Vulnerability Index (CVI) in this paper were referred to Boruff et al. [6] and DKP [7]. The specific weighting physical variables are shown in Table 3. In this study, the coastal vulnerability assessments were undertaken based on these 10 variables such as the coastal physical susceptibility to cause disasters due to the erosion occurrences.

Table 3. The weighting of coastal physical variables

\begin{tabular}{|l|l|l|l|l|l|}
\hline \multirow{2}{*}{ Variable } & \multicolumn{5}{|c|}{ Weight } \\
\cline { 2 - 6 } & $\mathbf{1}$ & $\mathbf{2}$ & $\mathbf{3}$ & $\mathbf{4}$ & $\mathbf{5}$ \\
\hline $\begin{array}{l}\text { Coastline } \\
\text { Changes } \\
\text { (PP) }\end{array}$ & $0 \mathrm{~m} /$ year & $(0-1) \mathrm{m} /$ year & $(1-5) \mathrm{m} / \mathrm{year}$ & $(5-10) \mathrm{m} / \mathrm{year}$ & $>10 \mathrm{~m} / \mathrm{year}$ \\
\hline $\begin{array}{l}\text { Visual } \\
\text { observation } \\
\text { of damage } \\
\text { (K) }\end{array}$ & $\begin{array}{l}\text { Visible } \\
\text { symptoms of } \\
\text { damage }\end{array}$ & $\begin{array}{l}\text { Seen scoured } \\
\text { but still stable }\end{array}$ & $\begin{array}{l}\text { Scoured and } \\
\text { there will be } \\
\text { a collapse }\end{array}$ & $\begin{array}{l}\text { Scouring and } \\
\text { collapsing but } \\
\text { not yet harm } \\
\text { to the } \\
\text { facilities/ } \\
\text { infrastructure }\end{array}$ & $\begin{array}{l}\text { Scouring and } \\
\text { ruins and } \\
\text { potentially } \\
\text { endangering } \\
\text { the facilities/ } \\
\text { infrastructure }\end{array}$ \\
\hline $\begin{array}{l}\text { Length of } \\
\text { Damage }\end{array}$ & $<0.5 \mathrm{~km}$ & $0.5-2.0 \mathrm{~km}$ & $2.0-5.0 \mathrm{~km}$ & 5.0-10.0 km & $>10 \mathrm{~km}$ \\
\hline
\end{tabular}




\begin{tabular}{|c|c|c|c|c|c|}
\hline \multirow{2}{*}{ Variable } & \multicolumn{5}{|c|}{ Weight } \\
\hline & 1 & 2 & 3 & 4 & 5 \\
\hline$(\mathrm{PK})$ & & & & & \\
\hline $\begin{array}{l}\text { Width of } \\
\text { Damage } \\
\text { (LK) }\end{array}$ & $0 \mathrm{~m}$ & $1-10 \mathrm{~m}$ & $10-50 \mathrm{~m}$ & $50-100 \mathrm{~m}$ & $>100 \mathrm{~m}$ \\
\hline $\begin{array}{l}\text { Green Belt } \\
\text { Width }(\mathrm{SH})\end{array}$ & $>1500 \mathrm{~m}$ & $(1000-1500) \mathrm{m}$ & $(500-1000) \mathrm{m}$ & $(50-500) \mathrm{m}$ & $<50 \mathrm{~m}$ \\
\hline $\begin{array}{l}\text { Lithology } \\
\text { (L) }\end{array}$ & $\begin{array}{l}\text { Rocks are } \\
\text { frozen, } \\
\text { sedimentary, } \\
\text { compact and } \\
\text { hard }\end{array}$ & $\begin{array}{l}\text { Sedimentary } \\
\text { rock, fine- } \\
\text { grained, soft }\end{array}$ & $\begin{array}{l}\text { Gravel and } \\
\text { coarse sand }\end{array}$ & $\begin{array}{l}\text { Fine sand, } \\
\text { silt, soft clay }\end{array}$ & $\begin{array}{l}\text { Fine sand, silt, } \\
\text { clay, soft }\end{array}$ \\
\hline $\begin{array}{l}\text { Wave } \\
\text { Height }(\mathrm{H})\end{array}$ & $<0.5 \mathrm{~m}$ & $(0.5-1) \mathrm{m}$ & $(1-1.5) \mathrm{m}$ & $(1.5-2.0) \mathrm{m}$ & $>2.0 \mathrm{~m}$ \\
\hline $\begin{array}{l}\text { Tidal Range } \\
\text { (PS) }\end{array}$ & $<0.5 \mathrm{~m}$ & $(0.5-1) \mathrm{m}$ & $(1-1.5) \mathrm{m}$ & $(1.5-2.0) \mathrm{m}$ & $>2.0 \mathrm{~m}$ \\
\hline $\begin{array}{l}\text { Land Use } \\
(\mathrm{PL})\end{array}$ & $\begin{array}{l}\text { Tackles, } \\
\text { mangrove } \\
\text { forests, } \\
\text { vacant lots } \\
\text { and swamps }\end{array}$ & $\begin{array}{l}\text { The domestic } \\
\text { tourist areas } \\
\text { and traditional } \\
\text { ponds }\end{array}$ & $\begin{array}{l}\text { Rice fields } \\
\text { and intensive } \\
\text { ponds }\end{array}$ & $\begin{array}{l}\text { Settlements, } \\
\text { ports, offices, } \\
\text { schools, } \\
\text { provincial } \\
\text { roads }\end{array}$ & $\begin{array}{l}\text { Cultural } \\
\text { preserve, } \\
\text { tourist areas, } \\
\text { industry, } \\
\text { country roads } \\
\text { and air defense } \\
\text { facilities }\end{array}$ \\
\hline $\begin{array}{l}\text { Beach slope } \\
(\tan \alpha)\end{array}$ & $0-2 \%$ & $2-5 \%$ & $5-10 \%$ & $10-15 \%$ & $>15 \%$ \\
\hline
\end{tabular}

\subsection{Weighted priority for mitigating the beach based on multi criteria}

The weighted priority is based on four main variables; physical, socio-economy, environment and strategic aspects (Table 4). Table 4 was developed during the Forum Group Discussion (FGD) meeting at the Riau Public Work Department, in November 2017.

Table 4. Weighing priorities for managing the damaging coast.

\begin{tabular}{|c|c|}
\hline Weighted criteria & Weight (\%) \\
\hline Technical aspects & 40 \\
\hline Strategic areas aspect & 30 \\
\hline Socio-economic aspects & 20 \\
\hline
\end{tabular}




\begin{tabular}{|c|c|}
\hline Environmental aspects & 10 \\
\hline Total & 100 \\
\hline
\end{tabular}

Based on the weighting priorities for Managing the Damaging Coast, the results will be used as a guideline for the prioritizing the coastal mitigation strategies.

\section{Results and discussion}

\subsection{The technical coastal vulnerability analyses}

The results of the coastal vulnerability analysis have yielded the following Coastal Vulnerability Assessment Fig. 3 (a). The assessment of the coastal vulnerability has yield three beaches with appointed as the highest vulnerability index coastline such as in Bantar, Tanjung Motong with a score of 244.95, Pambang Coast with a score of 277.95, then it was followed by Tanah Merah Beach with a score of 212.13.

\subsection{Socio-economic analysis}

The socio-economic variables were based on a scale of one to five, based on these variables the results can be seen in the following figure (Fig. (3b)). Based on the results of the socioeconomic analysis, it is identified that the highest score of this variable was 2.55 which was occurred in the village of Pambang Pesisir and Tanah Merah beaches.

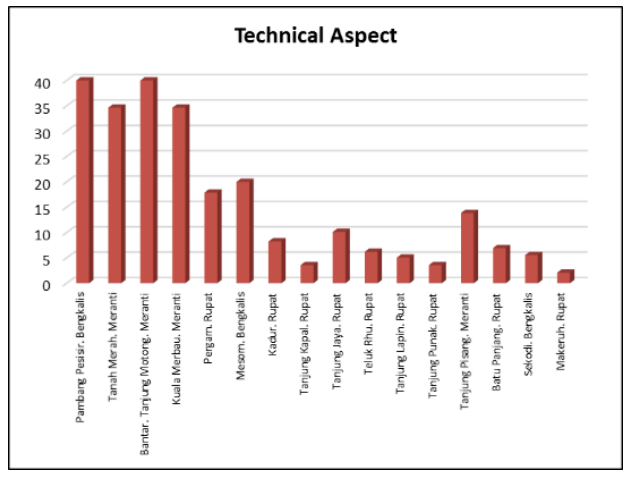

(a)

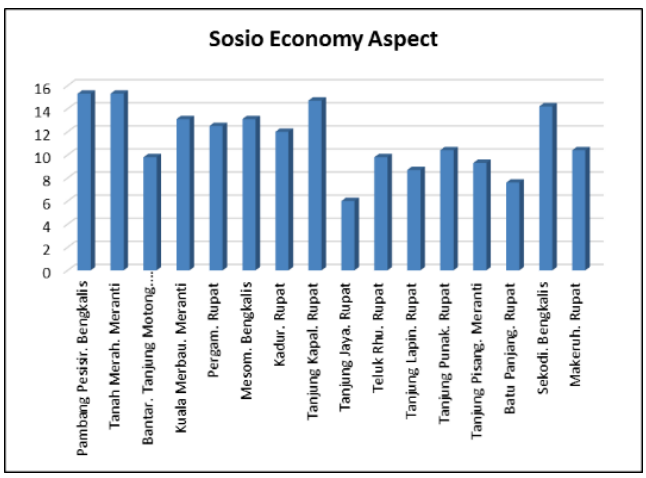

(b)

Fig. 3. (a) Coastal vulnerability assessment analysis results (technical aspect), (b) Socioeconomic aspect assessment.

\subsection{Environmental analysis}

Environmental variables concerning three parameters including accessibility, natural conservation, and wastes. Based on the results of the environmental analysis, it was identified that in general the ecological conditions in the coastal areas were in moderate condition with no severe environmental damage (Fig. 4 (a)).

\subsection{Strategic variable analysis}


Based on these strategic variables, each coast is classified according to the following assessment: 1) 00-25: The beach location is not at the local strategic area, 2) 25-50: The beach location is considered in the local strategic area, 3) 50-75: The beach location is considered in the National strategic area which is included in the National Tourism Plan, 4) 75-100: The location is considered in the local strategic area, National strategic area, and stated in the National Tourism Strategic Plan. Based on these conditions, the results can be seen in the following table (Fig. 4 (b)). It was identified that the Pambang Pesisir, Tanah Merah, Tanjung Kapal, and Sekodi as significant to be mitigated in the light of a strategic variable.

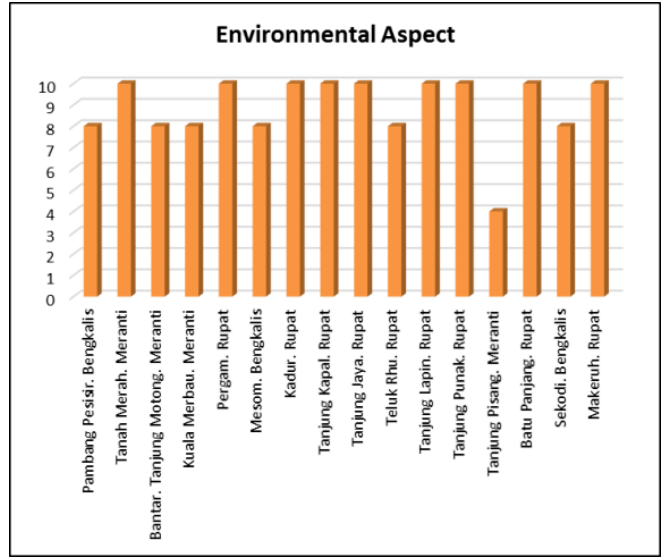

(a)

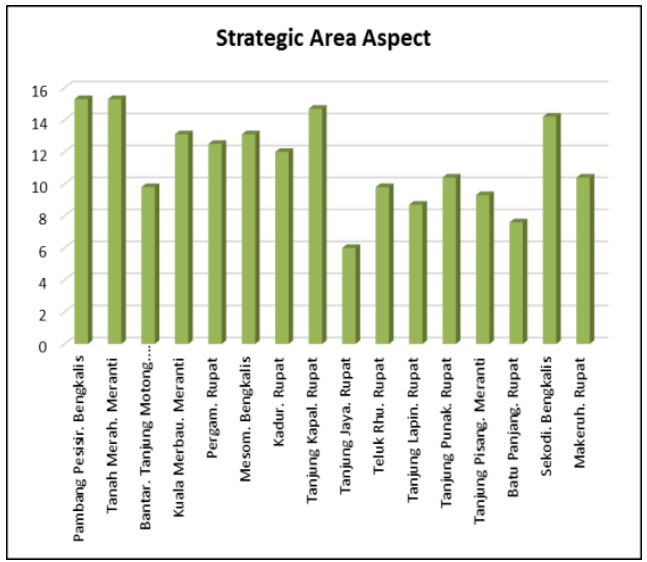

(b)

Fig. 4. (a) Environmental aspect assessment analysis, (b) Beach weighted results by strategic area.

\subsection{The selection of coastal mitigation priorities}

Using equation $(1)$ of $(\mathrm{CVI})=(\sqrt{ }($ Multiplication of all variables $) /($ Number of Variables $)$, the final results were presented in the following Table 5. Based on the highest priority beach in need to mitigate is Pambang beach in Bengkalis Regency.

\subsection{Simulation of coastal mitigation measure}

The simulation was conducted with the highest priority of the beach in Riau e.i. Pambang Pesisir coast located in Bengkalis Island. This coastline is the most vulnerable beach in Bengkalis Island.

There were two developed scenarios of simulation. These encompass scene 1 (without the use of coastal protection structures), and scene 2 (with the use of a protection structure). 


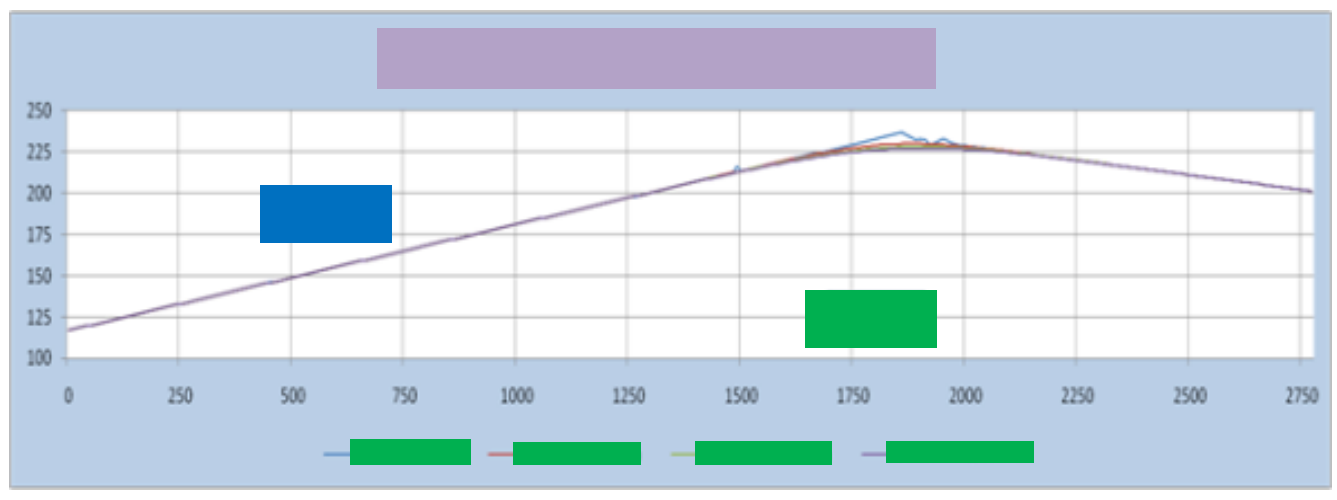

Fig. 5. Changes of coastline without coastal structure Pambang Pesisir Kab. Bengkalis.

Table 5. Coastal mitigation priorities.

\begin{tabular}{|c|c|c|c|c|c|c|c|c|c|c|}
\hline z & 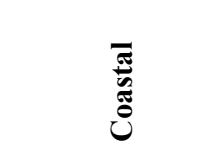 & 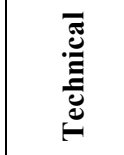 & है & 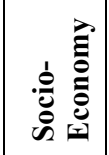 & t) & 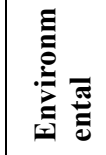 & 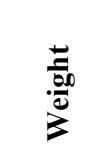 & 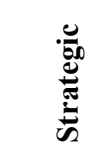 & $\frac{5}{50}$ & 疍 \\
\hline 1 & $\begin{array}{l}\text { Pambang } \\
\text { Pesisir. } \\
\text { Bengkalis }\end{array}$ & 244.95 & 40 & 2.55 & 15.3 & 4 & 8 & 60 & 12 & 75.3 \\
\hline 2 & $\begin{array}{l}\text { Tanah Merah. } \\
\text { Meranti }\end{array}$ & 212.13 & 34.6 & 2.55 & 15.3 & 5 & 10 & 75 & 15 & 74.9 \\
\hline 3 & $\begin{array}{l}\text { Bantar. Tanjung } \\
\text { Motong. Meranti }\end{array}$ & 244.95 & 40 & 1.64 & 9.8 & 4 & 8 & 80 & 16 & 73.8 \\
\hline 4 & $\begin{array}{l}\text { Kuala Merbau. } \\
\text { Meranti }\end{array}$ & 212.13 & 34.6 & 2.18 & 13.1 & 4 & 8 & 80 & 16 & 71.7 \\
\hline 5 & Pergam. Rupat & 109.54 & 17.9 & 2.09 & 12.5 & 5 & 10 & 50 & 10 & 50.4 \\
\hline 6 & $\begin{array}{l}\text { Mesom. } \\
\text { Bengkalis }\end{array}$ & 122.47 & 20 & 2.18 & 13.1 & 4 & 8 & 25 & 5 & 46.1 \\
\hline 7 & Kadur. Rupat & 50.6 & 8.3 & 2 & 12 & 5 & 10 & 75 & 15 & 45.3 \\
\hline 8 & $\begin{array}{l}\text { Tanjung Kapal. } \\
\text { Rupat }\end{array}$ & 21.91 & $\begin{array}{l}3.6 \\
\text { oastline }\end{array}$ & \begin{tabular}{|l|}
2.45 \\
Change \\
\end{tabular} & $\begin{array}{l}14.7 \\
\text { Without }\end{array}$ & \begin{tabular}{|l|}
5 \\
Structu
\end{tabular} & re & 80 & 16 & 44.3 \\
\hline 9 & $\begin{array}{l}\text { Tanjung Jaya. } \\
\text { Rupat }\end{array}$ & 61.97 & 10.1 & 1 & 6 & 5 & 10 & 80 & 16 & 42.1 \\
\hline 10 & Teluk Rhu. Rupat & Sẻz. 95 & 6.2 & 1.64 & 9.8 & 4 & 8 & 90 & 18 & 42 \\
\hline 11 & $\begin{array}{l}\text { Tanjung Lapin. } \\
\text { Rupat }\end{array}$ & 30.98 & 5.1 & 1.45 & 8.7 & $\mathbf{L a}$ & $\begin{array}{l}10 \\
\text { nd }\end{array}$ & 90 & 18 & 41.8 \\
\hline 12 & $\begin{array}{l}\text { Tanjung Punak. } \\
\text { Rupat }\end{array}$ & 21.91 & 3.6 & 1.73 & 10.4 & 5 & 10 & 75 & 15 & 38.9 \\
\hline 13 & $\begin{array}{l}\text { Tanjung Pisang. } \\
\text { Meranti }\end{array}$ & $\begin{array}{l}\text { Coastline } \\
84.85\end{array}$ & $\begin{array}{ll}\text { nitial } & \text { Co } \\
13.9 & \end{array}$ & $\begin{array}{l}\text { thine } 5 \text { years } \\
1.55\end{array}$ & $9.3^{\text {Coastlin }}$ & $\begin{array}{c}10 \text { years } \\
2\end{array}$ & $\begin{array}{l}\text { Coastline } 1 \\
4\end{array}$ & $\begin{array}{r}\text { ears } \\
50\end{array}$ & 10 & 37.1 \\
\hline 14 & Batu Panjang. & 42.43 & 6.9 & 1.27 & 7.6 & 5 & 10 & 60 & 12 & 36.6 \\
\hline
\end{tabular}




\begin{tabular}{|l|l|l|l|l|l|l|l|l|l|l|}
\hline & Rupat & & & & & & & & & \\
\hline 15 & Sekodi. Bengkalis & 33.94 & 5.5 & 2.36 & 14.2 & 4 & 8 & 25 & 5 & 32.7 \\
\hline 16 & Makeruh. Rupat & 12.65 & 2.1 & 1.73 & 10.4 & 5 & 10 & 50 & 10 & 32.4 \\
\hline
\end{tabular}

Scenario 1 has an aim to provide an overview of the shoreline changes that occur naturally over several years (Fig. 5). The modeling was carried out for 14 years with the primary input in the form of shoreline that has been divided into several sections with each section length is 10 meters. The wave fluctuation levels were forecasted for 14 years. According to the results obtaining from the GENESIS application software, it was identified that there was erosion occurrence, with the average rate of $\pm 0.69 \mathrm{~m} / \mathrm{year}$, with the total erosion rate of $9.73 \mathrm{~m}( \pm 10 \mathrm{~m})$ for 14 years.

Scenario 2. An installation of a $1000 \mathrm{~m}$ long revetment. After conducting this beach mitigation measure by installing the revetment structure, there was a significant reduction in the coastline abrasion rate to become $\pm 0.00 \mathrm{~m} /$ year. However, there was identified that some erosions may still occur at the edge of the revetment structures, the amount of erosion is not significant.

\section{Conclusions}

Based on the results of the priority analysis of the coastal mitigation measures consist of 4 main aspects such as the level of physical vulnerability variables, socioeconomic aspects, environmental aspect, and strategic issues aspect, then it was recommended to prioritize managing the coastlines in Riau by the following order; Pambang Pesisir, Bengkalis, Tanah Merah, Meranti Islands, and Bantar. Meranti. The result of the numerical modeling shows that the construction of revetment in Pambang Pesisir beach may reduce the abrasion at the significant rate from $10 \mathrm{~m} / 14$ years to become $0 / 14$ year.

We would like to thank the Civil Engineering Faculty, Universitas Riau for technically facilitating this research study. We also thank the Public Work Department Riau Province for their contributions in the field survey, and Bengkalis, and Meranti Islands local Governments' supports.

\section{References}

1. R. Dahuri, J. Rais, S.P. Ginting, M.J. Sitepu, Sumber daya wilayah pesisir dan lautan secara terpadu (Pradnya Paramita, Jakarta, 2001)

2. Wahyudi, Prosiding Seminar Nasional Teori dan Aplikasi Teknologi Kelautan (2008)

3. A. Sandhyavitri, S. Sutikno, K. Yamamoto, M. Haidar, Int. J. of Eng. and Tech. 9, 3 (2017)

4. G. Kaiser, Forum DKKV/CEDIM: Disaster Reduction in Climate Change (2007)

5. E. Doukakis, European Water 11, 12 (2005)

6. B.J. Boruff, C. Emrich, S.L. Cutter, J. of Coastal Res. 21, 5 (2005)

7. DKP, pedoman penyusunan rencana pengelolaan garis pantai (Jakarta, 2004)

8. P.A. Abuodha, C.D. Woodroffe, International assessment of the vulnerability of the coastal zone to climate change (Australian Greenhouse Office, Australia, 2006)

9. M.L. Olivo, Climate Res. 9 (1997)

10. J.C. Ferreira, J. of Coastal Res. 39 (2004) 
11. Wahyudi, T. Hariyanto, Suntoyo. Analisa kerentanan pantai di wilayah pesisir pantai Utara Jawa Timur (ITS, Surabaya, 2009)

12. Sugiyono, Metode penelitian kuantitatif kualitatif dan $R \& D$ (Alfabeta, Bandung, 2008)

13. Akdon, S. Hadi, Aplikasi statistika dan metode penelitian untuk administrasi dan manajemen. (Dewa Ruchi, Bandung, 2005) 